\title{
THE APPLICATION OF DOW CHEMICAL'S PERFLUORINATED MEMBRANES IN PROTON-EXCHANGE MEMBRANE FUEL CELLS
}

G. A. Eisman

Dow Chemical Company

Freeport, Texas

Dow Chemical's research activities in fuel cell devices revolves around the development and subsequent investigation of the perfluorinated ionomeric membrane separator useful in proton-exchange membrane systems. Work is currently focusing on studying the effects of equivalent weight, thickness, water of hydration, pretreatment procedures, as well as the degree of water management required for a given membrane separator in the cell. The presentation will include details of certain aspects of the above as well as some of the requirements for high and low power generation. 